DOI: 10.22616/REEP.2020.043

\title{
Development of Design Thinking in the Field of Design and Crafts
}

\author{
Baiba Briede ${ }^{1}$ Dr.paed.; Zane Beitere-Selegovska ${ }^{2}$ Mg.paed. \\ Aija Pridane $^{3}$ Dr.paed.; Laura Boldisevica ${ }^{4}$ Mg.oec. \\ Latvia University of Life Sciences and Technologies, Faculty of Engineering, \\ Institute of Education and Home Economics, Latvia \\ baiba.briede@1lu.lv¹; zane.beitere@1lu.lv²; aija_pridane@inbox.lv³; laura.boldisevica@1lu.lv
}

\begin{abstract}
Design thinking is a complicated and time-consuming process that consists of various stages. It helps planning business development. Design thinking is centred on the solution of the problem and creation of desirable outcome. Design thinking is revealed as critical, creative and analytical way of thinking oriented towards reaching better results and improves one's life. The aim of the study is to analyse design thinking concepts and stages in relation to modern design nature, and reflect the invention of design thinking at university and school in the field of design and crafts. The methods used in the study are: the theoretical analysis of design thinking concepts and its stages, and empirical investigation of the usage of learning of design thinking in the particular courses for design and crafts students at Latvia University of Life Sciences and Technologies (LLU) and in the lessons of home economics and technologies at Jelgava Secondary School No. 4. As a result of the theoretical analysis, the authors assessed which definition and which stages of design thinking are the most appropriate for the implementation of the empirical study. The results were obtained from LLU study curriculum "Design and Crafts" courses and school subject "Home Economics and Technologies". The significance of the results manifests in comparison and assessment of design thinking concepts and stages, and opportunities of their implementation at university courses and school subject as well as reflects the holistic picture and reveals pluses and minuses in the learning process.
\end{abstract}

Keywords: design thinking, design thinking stages, design and crafts education.

\section{Introduction}

Solving complex problems is an everyday life almost for every person who is oriented towards reaching career goals. A situation becomes more complicated when an individual starts business and makes products. It means that more effective ways of reaching goals should be found out and design thinking is one of that tools. Design thinking is a way how to think and act, and a design professional should go through a number of stages starting from investigation of clients' needs up to implementation of product making and selling by meeting customers' demands.

Design is a strategic development process that provides a way to see and deal with different types of problems. In both business and academic environments, design is described as an instrument for creating and delivering innovative solutions. This innovation-driven resource is a major competitive advantage that can bring economic added value to public organizations, benefit regions and boost competitiveness in the business environment, and also promote learners' skills in the educational process to address challenges and create new ideas. Moreover, when a design is fully integrated into the innovation process, it can create added value in the development of products and services (Thomson, 2012).

From the year 2020/2021 the acquisition of a new competence-based education standard and curriculums are launched in Latvian schools. The subject "Design and Technologies" is developed instead of the subject "Home Economics and Technologies" (Noteikumi par valsts..., 2018).

Unlike the currently existing curriculum in which pupils learned a variety of tools for crafting and producing a variety of products, the new curriculum "Design and Technologies" enables basic school pupils (form 1-9) to gain understanding of how design solutions useful for people such as products, services, information and environmental solutions can be developed practically. Therefore, the training process focuses heavily on the deliberate planning and implementation of design steps, addressing the design process challenges, testing a number of possible solutions and producing prototypes to reach a complete outcome. Similarly, a key part of the learning process is the reflection of work process by recording and documenting the most important stages of development (searching for information on the specific situation/problem, creating ideas, sketches, drawings, attachments, recipes as well as planning, developing and testing. 
The secondary school in Latvia is passing over to three levels: basic, optimal and higher. This enables students to continue to know the different aspects of global affairs (products) and digital solutions, producing not only handmade products using tools and devices but also machines and automated means. The experience of engineering and technological challenges acquired in basic education the secondary school pupils develop interdisciplinary which is a result of several teaching fields co-operation. They acquire technologies in close connection with science and mathematics. The students form an understanding on technological processes in industry, practical usage of science achievements in the development of technologies. They also learn to assess the usage of technologies and products in line with the principles of sustainable development, ethics and economics as well as draft recommendations for their improvements. The students have to work out interdisciplinary projects for the development of entrepreneurship in the frame of in-depth courses. They can be training companies, exhibitions of their products, markets et cetera. The students on the secondary school optimal and higher levels have a planned opportunity to choose acquiring of several modules in line with their future career goals in particular higher schools of study curriculums (Noteikumi par valsts..., 2019).

Seven stage model of design thinking (Bušmanis, Bušmane, Adamoviča, 2018) could be recognised both in the curriculums in high and higher schools as well as in business. It is a convenient and compact way of thinking and a tool for reaching goals.

LLU Bachelor's Curriculum "Design and Crafts" comprises three directions: wood, metal and textiles design. The development of directions is focused on the usage of modern technologies, findings in the field of design and creative strategies and techniques how to develop design thinking. For instance, an informative example is in the direction of textiles where production of smart textiles of healthcare (Mečnika et al., 2014) is necessary and prospective nowadays' industry.

That is why the aim of the study is to analyse design thinking concepts and stages in relation to modern design nature, and reflect the invention of design thinking at university and school in the field of design and crafts.

\section{Methodology}

The task of the study was to analyse theoretically the concept of design thinking and its stages, The method used was an empirical investigation of the usage of learning of design thinking in the particular courses for design and crafts students at Latvia University of Life Sciences and Technologies and in the lessons of home economics and technologies at Jelgava Secondary School No. 4.

The study had been carried out from January 2019 to November 2019.

The theoretical analysis on design thinking is based on P.G. Rowe (1987), K. Best (2006), R. Razzouk and V. Shute (2012), Ch. Bušmanis, E. Bušmane, S. Adamoviča (2018), T. Brown (2020), R.F. Dam, Y.S. Teo (2020) scientific findings.

\section{The nature of design thinking}

The European Design Leadership Board established in 2011 promotes design and innovations in European. The Board considers design "..as an activity of people-centred innovation by which desirable and usable products and services are defined and delivered. A sector in its own right of specialised, professional economic activity by trained and qualified practitioners and as a tool for business and organisational growth at the highest strategic level. In addition to its economic benefits, design also encompasses sustainable and responsible behaviour contributing positively to an innovative society and improved quality of life" (Thomson, 2012).

Talking about design oriented to a client's needs and wishes often is started with ideas by industrial designer Tim Brown who developed "user-centred" design as well as the concept of "design thinking" (Great Design Thinking..., 2017). He substantiates that the space of design thinking is "desirability, viability and feasibility". These three key words originate from the definition that "Design thinking is a human-centered approach to innovation that draws from the designer's toolkit to integrate the needs of people, the possibilities of technology, and the requirements for business success" (Brown, 2020).

There are several recognisable findings describing the development of design thinking and which are used in the educating designers. P.G. Rowe (1987) developing design thinking in architecture and urban 
planning outlined a systemic understanding of design process offering the analysis of case studies of designers in real situations, and the importance of such design thinking key words as problem solving skills, attitude, creativity, finding of coherence, context, invention of ideas, decision making and others. They are crucial on every stage of design thinking and a lot of strategies are used to train becoming designers to reach multi-sided understanding of them and be skilful in various situations.

In the article on design thinking R. Razzouk and V. Shute analysed "the nature of design thinking, experts' behaviour in design, and differences between novice and expert designers". After deep analysis of findings, the authors summarize that "Having good design thinking skills can assist in solving really complex problems as well as adjusting to unexpected changes. Although the design process involves in-depth cognitive processes which may help our students build their critical thinking skills (e.g., reasoning and analysis) - it also involves personality and dispositional traits such as persistence and creativity" (Razzouk, Shute, 2012).

The scope of design thinking is wide and deep enough and it causes systemically organised approach in design education through a number of stages covering the development of all necessary qualities of the $21^{\text {st }}$ century designer.

Design thinking is a methodology for practical and innovative solutions to problem situations. It includes the process of generating ideas, targeting and market analysis, the development, production and promotion of concepts and prototyping.

The ideas from the European Design Leadership Board (Thomson, 2012), K. Best (2006) and Kantar (How Design Thinking..., 2011) home page are that design thinking is an essential strategy both in business and education. It combines a number of ideas, research and management methods in a specific order to achieve the maximum possible effectiveness. It combines both the creative and analytical way of thinking, which sets out a crucial role in designing, producing, artworks, services and business models. Creative processes are transformed into practical and functional solutions. In addition, design thinking as a method makes it easy to understand and organise innovation in the development of new ideas. Design thinking is an effective method in design education that helps students to create innovative product concepts, generate new ideas and develop existing ones. This method helps to focus on user and sustainability-oriented solutions, taking into account the social, ethical and technological context of progress. Design thinking involves overcoming challenges, providing experience and creating motivation.

Ch. Bušmanis, E. Bušmane, S. Adamoviča (2018) define design thinking as a user-focused problem and challenge-solving methodology. It contains seven stages (understanding essence; "digging" deeper with going into details; creating an idea of a solution; creating a prototype making it effective; checking to users; presenting persuading people; implementation in life) and it is not a liner process because when an individual receives feedback and has to investigate definite things deeper rather than other ones.

A non-linear process also is a five-stage model. It includes the following stages: empathise; define a problem; ideate; prototype and test (Dam, Teo, 2020).

\section{Results and Discussion}

Seven stage design thinking model is used in the study because it is quite popular and convenient for usage and its implementation in curriculums helps to develop a way of systemic thinking how to manage one's business:

- stage 1 Understanding essence means going deeper in understanding of context, -self, others and situations;

- $\quad$ stage 2 Digging deeper with going into details means getting to know the specifics and checking assumptions concentrating on several points of interest;

- stage 3 Creating an idea of a solution means generating ideas and finding solutions of challenges;

- stage 4 Creating a prototype making it effective means testing ideas and expressing views;

- stage 5 Checking to users means testing solutions on customers and collecting their opinions and repetitive testing again;

- stage 6 Presenting persuading people means getting support from stakeholders;

- stage 7 Implementation in life means usage of various resources and experience to get success. 
A brief outlook on design thinking concept and stages is given before starting action strategies in each stage. The inclusion of design thinking stages in the LLU programme's "Design and Crafts" courses is graphically depicted in Table 1 .

Table 1

Acquiring of design thinking stages in the curriculum "Design and Crafts" at LLU

\begin{tabular}{|l|c|c|c|c|c|c|c|}
\hline \multicolumn{1}{|c|}{ Stage } & Stage 1 & Stage 2 & Stage 3 & Stage 4 & Stage 5 & Stage 6 & Stage 7 \\
\hline Intudy course & & & $\mathrm{x}$ & & & & \\
\hline $\begin{array}{l}\text { Interactive Methods and } \\
\text { Professional Communication }\end{array}$ & $\mathrm{x}$ & $\mathrm{x}$ & $\mathrm{x}$ & & & & \\
\hline Product Design & $\mathrm{x}$ & $\mathrm{x}$ & $\mathrm{x}$ & $\mathrm{x}$ & $\mathrm{x}$ & $\mathrm{x}$ & $\mathrm{x}$ \\
\hline Interior Design & $\mathrm{x}$ & $\mathrm{x}$ & $\mathrm{x}$ & & & & \\
\hline $\begin{array}{l}\text { Experimental Visual and Creative } \\
\text { Thinking }\end{array}$ & $\mathrm{x}$ & $\mathrm{x}$ & $\mathrm{x}$ & $\mathrm{x}$ & $\mathrm{x}$ & & \\
\hline $\begin{array}{l}\text { Fundamentals of Design and } \\
\text { Product Registration }\end{array}$ & $\mathrm{x}$ & $\mathrm{x}$ & $\mathrm{x}$ & & & & \\
\hline Basics of Crafts & $\mathrm{x}$ & $\mathrm{x}$ & $\mathrm{x}$ & $\mathrm{x}$ & $\mathrm{x}$ & & \\
\hline
\end{tabular}

During the first stage students acquire techniques how to understand context, others and situation. They use techniques how to find a contact with people and comprehend their view, ideas, dreams and challenges. It is crucial perspective in this stage that a focus is on a client's ideas and imagination rather than a designer's professional knowledge. It is because the designer has to come closer to the client's thinking and step by step both parts create the final solution. That is why becoming design specialists have to use techniques of observing people and trying to understand and make notes on their taste and motivation of usage particular products. They also use the technique of making the potential clients' profiles describing their interests, values, goals, needs, habits, capabilities, occupations, age and ways how they could improve their well-being. So, it is possible to make the clients' register.

The first stage also involves the investigations of designers' personality. Here the SWOT (strong and weak sides, opportunities and threats) technique and description of one's future business is practised. Students write about their future companies personalising them. It means that they describe such companies' interests, values, hobbies, dreams, favourite products, groups of interest, activities and favourite media. It helps a professional to understand how he/she differs from clients and opportunities to inspire them.

The second stage comprises deeper understanding of one's interests and students perform a task about their company, time management. The students learn to create interviews and how to use questions as well as drawing and analysing "a problem tree" by means of which try to understand deeper the causes of problems and consequences.

During the third stage students try a lot of creative methods in many courses. For example, in the course "Interactive Methods and Professional Communication" they complete tasks using "Mind Map" (Sicinski, 2018), "Mind Provocation" (Creative Provocation, Reverse..., 2018), "Morphological Box" (Burge, 2016), "Osborn's Checklist" (Osborn, 1963; Osborn's Checklist, 2020) methods. Whereas in courses "Introduction in Studies" and "Basics of Crafts" they are working on associations through creativity and innovation training methods, such as exercises to develop creative thinking by de Bono (2007) or different gamestorming methods (Gamestorming is a set..., 2020).

A lot of methods in study course "Introduction in Studies" are used by working in groups which are mixed each time because groups are more likely to solve the problem than individuals. In turn a group work trains students for a real work environment, understanding how hard it is to work in a team or with clients.

During the prototyping stage students are exploring idea realization. They are testing materials, technologies, shape and ergonomics aspects to get the best result.

During the fifth stage students give made prototype to test to family, friends and course-mates or real client if it is possible. For best results testing is productive on strangers and course-mates are excellent auditorium for it because they are quite critical to each other. 
For getting best results this is a moment when previous stages have to be revised to look for better solutions. First prototype never is the best result, but in study process not always are possibilities and time to repeat process more times so sometimes students are asked to make conclusions on how they would upgrade product without real upgrades. Repetition is an important step in the design process that allows for better adaptation of specific context, quickly understand errors and make improvements.

During the last stages students are thinking about strategies to implement product in market, making visual materials and presentations to reach target market.

In nowadays school learning of seven design thinking stages is implemented in the subject "Design and Technologies".

First, in order to create ideas, pupils should be aware of their own and other needs and opportunities in the context of the creation of a specific product. The pupil also should be aware of his/her capacity and the availability of resources (materials, technologies, time and tools) necessary for specific activities.

The next step is looking for ideas and selecting a solution. Pupils have to learn the usage of variety of ideas considering whether the intended product will be necessary, sustainable, up to date, will not consume redundant materials and whether the same or similar solutions are already available on the market. The pupils also should prepare to consider alternatives of materials and techniques and justify their choice.

During the planning phase the pupil has to plan resources for sequent actions and solutions. Then the producing development phase follows in which the pupils practice skills to use particular techniques of material processing and then to make a product independently.

During the evaluation phase the pupils train to assess their skills in the work process and improve their performance quality. They also assess their design solution according to defined criteria.

During the testing and development phase of the design solution, in line with the predefined product characteristics and associated functionality, pupils learn to plan and perform the testing process, analyse results obtained by identifying the necessary changes to the design and output process of the product.

The final - instruction phase of the design solution involves presentation (narration, exhibition, product exposition, digital presentation or demonstration).

Pupils should find answers on the questions "How?", "With what?", "Why?" acquiring every theme in the subject "Design and Technologies".

When answering the question "How?" the pupil understands that products are created in the design process, that solutions are developed by means of specific work steps that begins with identifying the problem and creating ideas and ends with implementation the solution.

When answering the question "With what?" the pupil understands the importance of the choice of suitable and safe materials and technologies as well as the level of knowledge and skills to achieve a specific result.

In response to the question "Why?" pupils understand that design solutions depend on the needs, expectations and capabilities of a particular consumer and society. In this context the pupil has to figure out where to look for inspiration to find new solutions and how they can affect society and environment.

The goal of the subject "Design and technologies" is to enable the pupil to develop practical skills by working with a variety of technologically increasingly sophisticated tools, electrical tools and devices. The pupil gets skills to work with hand-tools and simple materials and in elementary school the pupil learns working with electrical tools and devices as well as uses technological devices such as sewing machines, lathes, programmed machine tools and household appliances.

This creates an understanding of what is learned, the advantages and disadvantages of hand work, the use of technologies and how to prefer them in different situations. Pupils learn the increasing scope of material processing gradually, so they are able better to choose the best suited technology for developing their ideas and creating the products of higher quality.

Development of design thinking in learning situations should be practised considering challenges, necessities and problems in everyday work-life in companies. Conclusions and recommendations from the companies is a significant factor of revising design thinking ideas and techniques in learning situations. 
McKinsey \& Company's study on design leaders responsibilities a stress is on "the organisation's design ambition, and to clarify the leadership needed to deliver it.." (Dalrymple, Pickover, Sheppard, 2020). Three "interconnected interventions" to raise the organisation's "design ambition" are recommended by the authors:

- "embrace user-centric strategies, improving not only products and services but also the full user experience and, in some cases, the organisation itself;

- embed your senior designer into the $C$-suite while cultivating a collaborative top-team environment in which your design leader will thrive;

- make the most of user data through a balance of quantitative and qualitative design metrics and incentives that enhance user satisfaction and business performance" (Dalrymple, Pickover, Sheppard, 2020).

The three interventions could be an effective tool for senior designers to promote design quality and entire business of every company.

In the Programme Mastering Design Thinking of Michigan Institute of Technologies nine steps of the development of design thinking are taught: learn concepts that derive design thinking, identify customer needs and user groups, create a prototype, analyse the economics of the innovation, present your final idea, get real-time feedback, submit your project ideas around user innovations, translate needs into product specifications, build out the product architecture, choose the right development process. The Programme is focused on both team and individual product developers and it helps business people to become more effective in thinking systemically, implementing product development, meeting customers' needs and challenges as well as overcoming obstacles in the problem-solving process (Management Executive Education, 2020).

\section{Conclusions}

Design thinking helps to systematize thinking and guidelines how a product can be developed and reach a customer. It is a methodology for practical and innovative solutions to problem situations. It includes the process of generating ideas, targeting and market analysis, the development, production and promotion of concepts, prototyping and implementation of production.

The implementation of the stages of design thinking develops deep knowledge and skills, and learning of them from the basic education means that pupils and students train both professional, social and meta- skills.

Design thinking has a universal character and it can promote goal reaching in every field of life rather than design.

The significance of the results manifests in comparison and assessment of design thinking concepts and stages, and opportunities of their implementation at university courses and school subject as well as reflects the holistic picture of learning design thinking.

\section{Bibliography}

1. Best K. (2006). Design Management: Managing Design Strategy, Process and Implementation. Switzerland: Ava Publishing SA.

2. Brown T. (2020). Design Thinking Defined. IDEO Design Thinking. Retrieved from https://designthinking.ideo.com/

3. Burge S. (2016). The Systems Thinking Tool Box. Rugby, UK: Burge Hughes Walsh. Retrieved from https://www.burgehugheswalsh.co.uk/Uploaded/1/Documents/Morphological-Box-Tool-v1-0.pdf

4. Bušmanis Ch., Bušmane E., Adamoviča S. (2018). Design thinking toolkit by "Design Elevator". Retrieved from https://www.fold.lv/en/2018/12/design-thinking-toolkit-by-design-elevator/

5. Creative Provocation, Reverse Brainstorming, and Analogy. (2018). Retrieved from https://www.allaboutlean.com/creative-provocation-and-others/

6. Dalrymple M., Pickover S., Sheppard B. (2020). Are You Asking Enough from Your Design Leaders? McKinsey Quarterly, February. Retrieved from https://www.mckinsey.com/ /media/McKinsey/Business\%20Functions/McKinsey\%20Design/O 
ur\%20insights/Are\%20you\%20asking\%20enough\%20from\%20your\%20design\%20leaders/Areyou-asking-enough-from-your-design-leaders.ashx

7. Dam R.F., Teo Y.S. (2020). Five Stages in the Design Thinking Process. Retrieved from $\mathrm{https}$ ://www.interaction-design.org/literature/article/5-stages-in-the-design-thinking-process

8. De Bono E. (2007). How to have creative ideas: 62 exercises to develop the mind. UK: McQuaig Group.

9. Gamestorming is a set of co-creation tools used by innovators around the world. (2020). Retrieved from https://gamestorming.com/

10. Great Design Thinking by Tim Brown. (2017). Retrieved from http://www.digitallysquared.com/great-design-thinking-by-tim-brown/

11. How Design Thinking Can Enrich Marketing and Business Innovation. Added Value. (2011). Retrieved from http://added-value.com/2011/11/08/how-design-thinking-can-enrich-marketingand-business-innovation/

12. Management Executive Education. (2020). MIT Management Executive Education. Retrieved from https://executive-ed.mit.edu/mastering-design-thinking.php

13. Mečnika V., Hoerr M., Krieviņš I., Schwarz A. (2014). Smart textiles for healthcare: applications and technologies. In V. Dislere (Ed.), The Proceedings of the International Scientific Conference Rural Environment. Education. Personality (REEP), 7. Jelgava: LLU, 150-161. Retrieved from https://llufb.llu.lv/conference/REEP/2014/Latvia-Univ-Agricult-REEP2014proceedings-150-161.pdf

14. Noteikumi par valsts pamatizglìtības standartu un pamatizglìtības programmu paraugiem [Rules on the National Standard of Basic Education and Samples of the Programmes of Basic Education]. (2018). Ministru kabineta noteikumi 747. Retrieved from https://likumi.lv/ta/id/303768 (in Latvian)

15. Noteikumi par valsts vispārējās vidējās izglìtības standartu un vispārējās vidējās izglìtības programmu paraugiem [Rules on the National Standard of General Secondary Education and Samples of the Programmes of General Secondary Education]. (2019). Ministru kabineta noteikumi 416. Retrieved from https://likumi.lv/ta/id/309597 (in Latvian)

16. Osborn A.F. (1963). Applied Imagination: Principles and Procedures of Creative ProblemSolving. New York: Charles Scribner's Sons.

17. Osborn's Checklist. (2020). University of Cambridge. Retrieved from https://www.ifm.eng.cam.ac.uk/research/dmg/tools-and-techniques/osborns-checklist/

18. Razzouk R., Shute V. What Is Design Thinking and Why Is It Important? (2012). Review of Educational Research, 82(3), 330-348. doi: 10.3102/0034654312457429

19. Rowe P.G. (1987). Design Thinking. Cambridge: MIT Press.

20. Sicinski A. (2018). The Complete Guide on How to Mind Map for Beginners. Retrieved from https://blog.iqmatrix.com/how-to-mind-map

21. Thomson M. (2012). Design for Growth and Prosperity: Report and Recommendations of the European Design Leadership Board. Helsinki, Finland: DG Enterprise and Industry of the European Commission. Retrieved from http://europeandesigninnovation.eu/wpcontent/uploads/2012/09/Design_for_Growth_and_Prosperity_.pdf 